\title{
Prenatal Education Process Based on Local Wisdom in Indonesia
}

\author{
St. Wardah Hanafie Das (D), ${ }^{1}$ Abdul Halik $\mathbb{D}^{2},{ }^{2}$ Ahdar $\mathbb{D}^{2},{ }^{2}$ and Bustanul Iman (D) $^{2}$ \\ ${ }^{1}$ Universitas Muhammadiyah Parepare, Parepare, Indonesia \\ ${ }^{2}$ Institut Agama Islam Negeri Parepare, Parepare, Indonesia \\ Correspondence should be addressed to St. Wardah Hanafie Das; wardahhadas@gmail.com
}

Received 16 September 2021; Revised 14 December 2021; Accepted 27 December 2021; Published 27 February 2022

Academic Editor: Ehsan Namaziandost

Copyright $\odot 2022$ St. Wardah Hanafie Das et al. This is an open access article distributed under the Creative Commons Attribution License, which permits unrestricted use, distribution, and reproduction in any medium, provided the original work is properly cited.

\begin{abstract}
The pregnant activities, namely, the existence of classes for pregnant, can add insight and knowledge about pregnancy, pregnancy care, childbirth, and postpartum through educational counseling conducted by competent health workers. During the pregnancy, the women should remain in harmony with others to avoid stress, and the most important point is to always consume nutritious food for health. Good behavioral education for pregnant women includes social accommodation, forming friendships with family and neighbors, helping others, and tending to control emotions during pregnancy. Nutritional education during pregnancy includes knowledge about nutritional issues for pregnant women, how to consume nutritious foods and drinks, and the benefits of nutrition for mothers and fetuses. All pregnant women studied used a Sanro (shaman) to accompany them during pregnancy until delivery, even though there were medical personnel. Local wisdom becomes part of the approach in childbirth, to accompany them during pregnancy until delivery, even though there are health workers. Prenatal education models are still used by the pregnant women, especially in rural areas of Indonesia.
\end{abstract}

\section{Introduction}

Children at the present time are the next generation of the nation. Pregnant mothers should pay attention to children that are still in their womb because the next period is primarily determined by the period of the child in the womb [1]. The prenatal period is critical for the baby's physical, emotional, and mental development [2]. This period is when the close relationship between baby and parents begins to form with long-lasting consequences [3]. Pregnant women class is a study group with a maximum number of 10 participants with a gestational age of between 4 weeks and 32 weeks (before delivery) [4]. All pregnant women will learn together and share experience related to how to care themselves during pregnancy until childbirth [5]. Counseling to pregnant women is carried out regularly and continuously [6].

Medically, pregnant women get high service and no longer need to consult "Sanro" (maternity shaman). However, pregnant women have their own beliefs of inviting
"Sanro" for consultation as local wisdom. Medical personnel generally relent and follow the wishes of pregnant women, who still consult Sanro, for the safety of the fetus. Medical personnel following pregnant women's desires can make them happy and happy unless there are things that can threaten the mother and fetus's health. Pregnant women tend to feel more confident if always close to Sanro, so pregnant women always follow the rituals performed by Sanro. Multidimensional prenatal education requires an indepth study, as there is often a clash of bases and orientations.

There must be a wise and precise formulation in formulating the meeting point of the three approaches, namely, culture approach, religion approach, and medical approach. Medical and religion (especially Islam as the religion of most pregnant women) are open to going hand in hand and integrating epistemologically. The local cultural approach (Sanro) has its epistemological dimension and requires indepth study to have strong complementary relationships in the prenatal education formula. Remote communities are 
closer to the realm of local wisdom (culture and religion) and require strategies to socialize medical approaches to improve the quality of public health, especially prenatal education.

There are several relevant studies, including those by Wahyu [2] entitled Development in the Prenatal and Birth Period; Elizawarda [7] entitled The Relationship of PostTerm Pregnancy and the Incidence of Asphyxiated Babies in RSUP. H. Adam Malik Medan; Kambali [8] entitled "Emotional and Intellectual Growth and Development in the Prenatal Period"; Nugraheni and Kuswati [4] entitled "Differences in Maternal Anxiety Levels in the Class of Pregnant Women in the Work Area of the Tulung Health Center"; and Utama and Eka [9] entitled Prenatal in Islamic Education: A Study of Parenting Patterns and Learning Materials for Islamic Education Perspectives on Children in the Prenatal Period. The researches above focus on (1) prenatal education; (2) preterm, mature, and postmature pregnancies; (3) prenatal emotional and intellectual development; and (4) anxiety of pregnant women.

The prenatal period is a critical period for the baby's physical, emotional, and mental development; this is a period in which the close relationship between the baby and parents begins to form with consequences that will have a prolonged impact, especially concerning the ability and intelligence of the baby in the womb ([3]: 20). Prenatal education is education given to children before birth or from the womb until the child is born. So, whatever parents do, that is the education given to children in the womb. Prenatal education is a conscious effort made by adults (as educators) to develop the potential possessed by every human being to grow optimally following their goals and education, which begins in the mother's womb (prenatal).

This study examined prenatal education in the class of pregnant women, local wisdom activities of the Bugis community related to the prenatal period, and the behavior of pregnant women as a model of prenatal education. The study aims to discover and formulate a prenatal education model for the class of pregnant women that synergizes local medical and wisdom approaches.

\section{Literature Review}

2.1. PrenatalEducation. Educating children in the womb is a big job that requires strong motivation, thought, patience, sacrifice, and absolute sincerity from the educators, namely, the parents ([10]: 55). Parents' understanding of the process of educational interaction between the fetus and parents is important [9]. The condition of the fetus in the womb is very vulnerable to its environment, namely, how much the mother has good health status, habits, and behavior or not [11]. During pregnancy, a mother must pay more attention to the condition of the physical and psychological development of the fetus, determine the sex and resemblance of the child and the reactions and movements of the fetus, maintain health for the sake of the fetus, provide healthy and comfortable nutritional intake, and continue with the birth process (postnatal) [12, 13].
Good education for the mother when she has not given birth, namely, during pregnancy, mainly pays attention to good foods and contains nutrients, vitamins, and high protein. Besides that, it also avoids eating dirty food or unclean food [14]. The fetus in its mother's womb grows and develops as a result of stimuli that come from outside (namely, its parents), both physically and psychologically [8]. Rasyim et al. [15] states that, during the period before birth, brain cells in the fetus have worked to receive messages related to touch, hearing, and motion, and the senses of taste, smell, and touch have developed. The steps taken by pregnant women so that their children get intake from an early age include reading, memorizing, thinking, counting, making music, singing; psychology (feeling control), communication, and humor [16].

2.2. Pregnancy. Manuaba and Chandranita [17] suggest that pregnancy is a continuous chain process and consists of ovulation, migration of spermatozoa and ova, conception and growth of the zygote, nidation (implantation) in the uterus, formation of the placenta, growth and development of the products of conception to term, and the gestation period, which is about 280 to 300 days [17]. Pregnancy is divided into pregnancy according to duration and pregnancy from parents. Pregnancy in terms of length pregnancy is divided into 3, namely, (1) premature pregnancy [7], namely, pregnancy between 28 and 36 weeks, (2) mature pregnancy [7], namely, pregnancy between 37 and 42 weeks, and (3) postmature pregnancy, namely, more than 43 weeks.

2.2.1. Medical Education. The existence of a class of pregnant women fostered in the Puskesmas area becomes a place for prenatal education with a medical approach. Experts state that when a child is in the womb, he can learn, know the difference between dark and light, and feel his parents' touch; that is why we need to educate him since he was still in the womb [18]. Medical coaching is fundamental to do and control the development of pregnancy. Furthermore, an evaluation was carried out on health workers and pregnant women in providing a material presentation to improve the quality of the learning system [6]

Educational steps for pregnant women are carried out from preparation to implementation of class learning for pregnant women, namely, identifying the number and age of pregnant women in the work area; preparing places and facilities for conducting classes for pregnant women; preparing materials, counseling aids, scheduling for the implementation of types for pregnant women, and studying the material to be delivered; preparation of pregnant women class participants, inviting pregnant women aged between 5 and 8 months. Prepare an implementation team for pregnant women classes, namely, the facilitators and resource persons if needed. Make a plan for the implementation of activities at the end of the meeting; exercise for pregnant women is carried out as an extra activity/material to determine the meeting time, which is adjusted to the readiness. 
2.2.2. Local Culture. Local wisdom in the context of Bugis culture has values in pregnancy care upheld by the community [19]. The concept of Sipakatau value in Bugis culture positions humans as God's noble creatures and therefore must be respected and treated well and implemented in harmonious social relationships marked by intersubjectivity and mutual respect as fellow beings [20]. Culture-based learning is a strategy for creating learning environments and designing learning experiences that integrate culture as part of the learning process [21]. Currently, the rituals that pregnant women in the Bugis community still carry out are Makkatenni Sanro and Ma'cera Wettang or Makkarawa Babua.

2.2.3. Frame. This study explores prenatal education that develops in communities with high health quality. Prenatal education synergizes local medical approaches and wisdom (Sanro and religion). The formulation of prenatal education is directed to pregnant women, with the conception that if pregnant women are healthy, it has implications for the fetus's health. Prenatal education requires strong synergy to maintain community identity while being open to the progress of science, especially in the field of medical and local wisdom.

Medical education for pregnant women is related to sports activities, gymnastics, and nutritional improvements suitable for pregnant women. Likewise, with the aspect of local wisdom that leads to Sanro's culture and religion, pregnant women ask Sanro to massage their stomach and improve the position of the fetus, which is done by the traditional way. The approach of local wisdom in the field of religion reinforces aspects of values and behavior because it is believed that what is done has substantial implications for the character and health of the fetus. The medical approach provides aspects of health so that the mother can maintain nutrition, physical stability, and health so that the fetus can grow and develop properly.

The formation of behavior for pregnant women is significant to undergo a healthy pregnancy. Three aspects are intended to form the behavior of the class of pregnant women, namely, education, local wisdom, and attitude. Here, the frame of mind of this research is shown in Figure 1.

\section{Methods}

This research method is development or research and development $(\mathrm{R} \& \mathrm{D})$, which develops educational equipment through thorough research using various techniques in a cycle that goes through multiple stages [22]. All steps in this research uses the R\&D method (Borg \& Gall [23]). Sugiyono [24] states that research and development (R\&D) is a research method used to produce specific products and test the effectiveness of these products. This research uses R\&D by describing clear and structured stages.

Sources of data in this research activity are classified into three parts: person, place, and paper, namely, symbols [25]. The personal aspect is the pregnant women class, the midwives as representatives of the Health Service, Islamic Religious Leaders, and Customary Stakeholders, as well as expert input and related stakeholders through FGDs, the place aspect is the pregnant women class in Sidenreng Rappang Regency, and the paper aspect is documents official at the District Education Office or Maternity Class Notes at the Puskesmas and the Pustu in every village or subdistrict, supporting data results from literacy studies and expert judgment and the consequences of focus group discussions.

The research instrument is the researcher himself as a planner, the implementer of data collection, analysis, and reporting of research results ([26]: 168). Data collection techniques used in the field are interview guidelines, observation guidelines, and documentation notes during the product trial process of $\mathrm{R} \& \mathrm{D}$ research. Qualitative data analysis is used in the Miles and Michael Huberman [27] model, namely, data reduction, data display, and conclusion drawing/verification, or with the stages: data reduction, organization, and interpretation [27, 29]. In this research, a technique for checking the validity of the data is needed [30]. Testing the validity of the data was carried out by persistent observation, triangulation, and preordering the validity of the data to prove whether the research conducted is scientific research and to test the data obtained. The data validity test in qualitative research includes credibility, transferability, dependability, and confirmability tests [31].

\section{Results}

The results of observations in the field show the daily activities of pregnant women and the activities of pregnant women in the class of pregnant women, namely,

(a) Pregnant women's daily activities

(1) There is no significant difference in daily activities for pregnant women and housewives who are not pregnant.

(2) Pregnant women generally studied still carry out their daily activities as housewives. After marriage, most women understood their duties as housewives, looked after and cared for their children, and cared for their husbands.

(b) Activities for pregnant women in maternity class

(1) The existence of classes for pregnant women can add insight and knowledge about pregnancy, pregnancy care, childbirth, and the postpartum period through educational counseling conducted by competent health workers.

(2) The material discusses about signs of labor, the danger signs of labor, the birth process, and postpartum care.

The content analysis contains two variables: prenatal education in medical review and local wisdom related to pregnancy as follows (Table 1). 


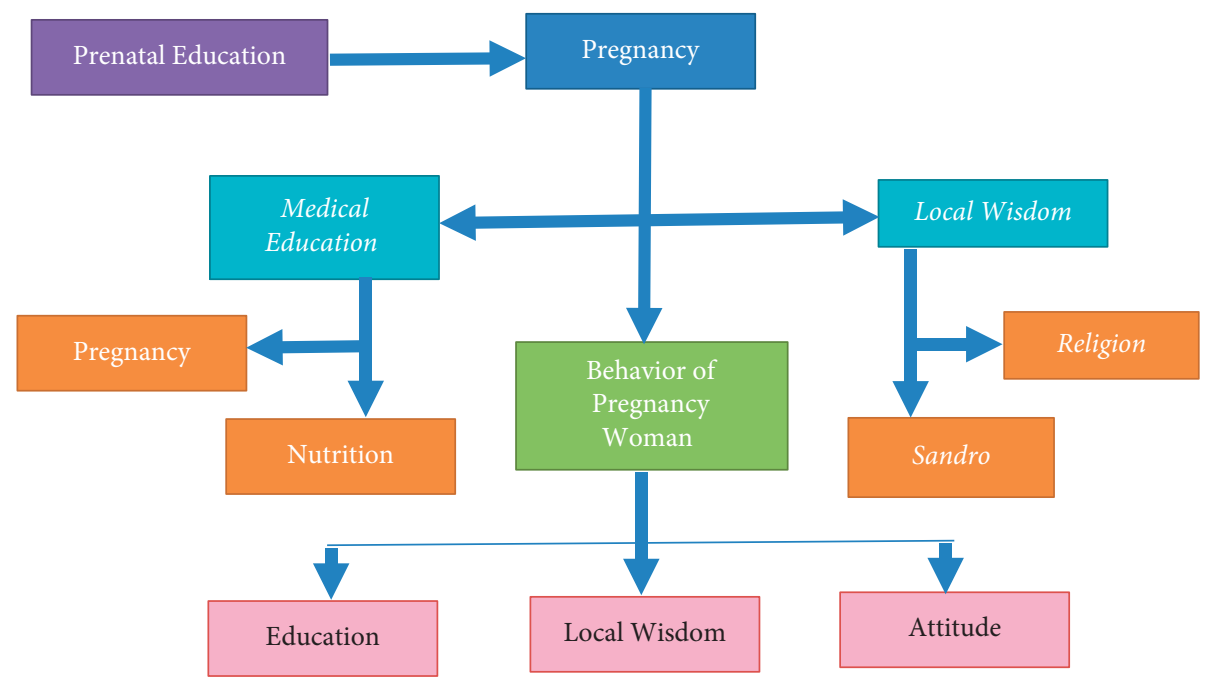

FIGURE 1: The formation of behavior for pregnant women.

Table 1: Prenatal education for pregnant women.

\begin{tabular}{|c|c|c|}
\hline No. & $\begin{array}{l}\text { Informant's } \\
\text { initials }\end{array}$ & Content analysis \\
\hline 1 & $\mathrm{SN}$ & $\begin{array}{l}\text { Attitude and pregnant mother behaviour } \\
\text { I like to help people, give charity so that other people can pray for me so that during pregnancy until the delivery } \\
\text { process can go well }\end{array}$ \\
\hline 2 & RW & $\begin{array}{l}\text { As for my good attitude and behavior, I do things like giving alms every Friday, helping others by giving } \\
\text { directions. Yes, I do it because I believe that a good deed will affect the child I carry }\end{array}$ \\
\hline 3 & ST & I don't know the benefits of behavior that affect my unborn child \\
\hline 4 & WD & $\begin{array}{c}\text { Regarding good behavior and good attitude during pregnancy, I did some of them by giving charity, friendship } \\
\text { with neighbors }\end{array}$ \\
\hline 5 & SR & As for good behavior and attitude, I do not know the benefits of behaving and behaving well during pregnancy \\
\hline 6 & $\mathrm{HN}$ & As for the activities of good behavior and attitude during pregnancy, I have helped people give charity to others \\
\hline 7 & WH & $\begin{array}{l}\text { As for good behavior and attitude during pregnancy, I often help people give charity to others, and during } \\
\text { pregnancy, I don't often get angry like most other pregnant women }\end{array}$ \\
\hline 8 & $\mathrm{KL}$ & $\begin{array}{c}\text { During my pregnancy, I also liked to help people, giving alms to those in need, although during pregnancy, I was } \\
\text { often angry }\end{array}$ \\
\hline 9 & SP & $\begin{array}{c}\text { For activities of good behavior and attitude during pregnancy, I like to help people, give charity, and sometimes } \\
\text { during pregnancy, I often get angry }\end{array}$ \\
\hline 10 & HL & $\begin{array}{c}\text { For activities with good behavior and attitude, I like to help others, give charity, and during pregnancy, I also often } \\
\text { get angry }\end{array}$ \\
\hline 11 & HD & $\begin{array}{l}\text { As for the activities of behaving and being good during pregnancy, I have helped people, giving charity, while my } \\
\text { attitude during pregnancy did not tend to be angry }\end{array}$ \\
\hline 12 & HS & $\begin{array}{c}\text { As for good attitudes and behavior, I did things like helping others and giving charity because my parents had } \\
\text { taught me that if I do good during pregnancy, it will affect the child's character later } \\
\text { Nutritional intake of pregnant women }\end{array}$ \\
\hline 1 & SN & $\begin{array}{l}\text { Regarding nutrition, regularly consume fruits such as mangoes, vegetables such as kale, consume single fish and } \\
\text { chicken meat, and drink formula milk. I finish it according to the advice of the midwife, but if there is a } \\
\text { relationship between food and fetal health, I have absolutely no knowledge about it }\end{array}$ \\
\hline 2 & RW & $\begin{array}{l}\text { Regarding nutrition, I regularly consume fruits such as apples, avocados. Vegetables in spinach, consume all types } \\
\text { of chicken and meat, and drink formula milk. The food I eat is according to the recommendations of my family } \\
\text { and health workers. About food-related to pregnancy, have no knowledge }\end{array}$ \\
\hline 3 & ST & $\begin{array}{l}\text { Regarding nutrition, I do not consume fruits, vegetables, milk during pregnancy, but I know the benefits of } \\
\text { providing nutrition during pregnancy. Regarding my nutrition, I regularly consume vegetables and fruits; the use } \\
\text { is only providing nutrition during pregnancy }\end{array}$ \\
\hline 4 & WD & $\begin{array}{l}\text { Regarding nutrition during pregnancy, I do not consume fruits, milk, chicken, meat, and the like, what I eat a lot } \\
\text { are vegetables and fish, and I do not know the benefits of nutrition during pregnancy }\end{array}$ \\
\hline 5 & SR & $\begin{array}{l}\text { Regarding nutrition during pregnancy, I often consume fruits such as apples, pears and also often consume fish, } \\
\text { and I do not know the benefits related to fruit }\end{array}$ \\
\hline
\end{tabular}


TABLE 1: Continued.

\begin{tabular}{|c|c|c|}
\hline No. & $\begin{array}{l}\text { Informant's } \\
\text { initials }\end{array}$ & Content analysis \\
\hline 6 & $\mathrm{HN}$ & $\begin{array}{l}\text { For nutritional provision during pregnancy, I often consume fruits such as bananas once a day, vegetables such as } \\
\text { kale twice a day, fish such as sponge fish once a day, and chicken once a day but do not consume too much milk } \\
\text { during pregnancy }\end{array}$ \\
\hline 7 & WH & $\begin{array}{l}\text { During pregnancy, I consume fruits such as apples, bananas once a day, vegetables such as kale, pumpkin once a } \\
\text { day, milk for pregnant women such as SGM milk once a day, fish, and chicken once a day. I do not consume } \\
\text { vitamins during pregnancy }\end{array}$ \\
\hline 8 & $\mathrm{KL}$ & $\begin{array}{l}\text { For nutritional provision during pregnancy, I often consume fruits such as apples and mangosteen once a day, } \\
\text { vegetables such as kale and mustard greens two times a day, milk such as lactam every day, fish such as milkfish } \\
\text { every day, and also chicken two times a week, tofu and the like three times a day and at any time drinking mango } \\
\text { juice three times a week I know the benefits of adequate nutrition during pregnancy can have a good impact on the } \\
\text { health of the mother and baby }\end{array}$ \\
\hline 9 & SP & $\begin{array}{l}\text { For nutrition during pregnancy, I often consume fruits such as avocado and apples once a day, vegetables such as } \\
\text { moringa leaves every day, Frisian flag milk twice a day, and fish while drinking avocado juice two times a week }\end{array}$ \\
\hline 10 & $\mathrm{HL}$ & $\begin{array}{l}\text { For nutrition during pregnancy, I often consume fruits, vegetables, fish, meat, and the like so that the fetus is in a } \\
\text { healthy womb }\end{array}$ \\
\hline 11 & HD & $\begin{array}{l}\text { For nutrition during pregnancy, I often consume fruits such as pears, vegetables such as carrots and eggplant, } \\
\text { consume lactam milk, eat fish, chicken, and the like; that is what I eat during pregnancy so that the fetus in the } \\
\text { womb remains healthy }\end{array}$ \\
\hline
\end{tabular}

Based on the information from the interview results of the informants above, it is divided into two parts, namely:

(1) Good Behavior. Good behavior of pregnant women shows that 11 informants said that they often practice good behavior or attitudes during pregnancy, such as giving charity, helping others, staying in touch, and knowing the benefits of good behavior and attitude for pregnancy. Then, one informant said that he had never done good behavior or attitude, apart from maintaining pregnancy

(2) Nutritional Intake. Nutrition of pregnant women showed that ten informants said that they consumed nutritious food and each of them knew the benefits of nutrition, for both the health of pregnant women and the fetus; one informant said that they consumed nutritious food but did not know the benefits for the health of pregnant women and fetuses, and then one informant said that he did not consume nutritious food and did not know the benefits of consuming nutritious food for pregnant women and fetuses.

From the results of in-depth interviews (Table 2) conducted by researchers about the local wisdom of the Bugis community related to the prenatal period, it was revealed that pregnant women used a Sanro (shaman) to accompany them during pregnancy until delivery, even though there was a midwife. Considering the pregnant women at 7 months of pregnancy in a local area in Indonesia, 75\% people still do the process, due to the encouragement of parents and social environment.

The review of the local wisdom of the Bugis community is to seek as much information as possible from pregnant women about culture, traditions, ceremonies, and so on related to their pregnancy.
(1) Makkatenni Sanro (Contacting Shaman). The delivery ceremony is given to the dukun selected based on the deliberation of the two families or advice from the community and parents. If the selection of the shaman is approved, the shaman will be given the trust to care for the mother and child later.

(2) Mappanre to Mangideng (Feeding Pregnant Women). It is a ceremony performed in the first month of pregnancy or in the Bugis tribe called cravings, usually passed by various kinds of events. In addition, it is forbidden to eat certain foods and perform specific actions, for both prospective mothers and prospective fathers.

(3) Ceremony of Seven Months of Pregnancy. In the Bugis language, bone is called Mappassili, which means bathing. The meaning of this ceremony is to repel reinforcements or avoid calamity or disaster and keep away from evil spirits so that all bad luck disappears and disappears.

The findings of pregnant women above are quoted from the results of in-depth interviews conducted by researchers about the local wisdom of the Bugis community related to the prenatal period. All pregnant women studied used a Sanro (shaman) to accompany them during pregnancy until delivery, even though there was a midwife. Regarding the 7-month event, 75\% of the pregnant women studied still do it, from the statement that the mother did the 7-month event at the will of their parents, inlaws, who in their neighborhood are still doing this activity.

The practice of pregnancy is one form of initiation, and it is only natural that, in the series of pregnancies, the community becomes full of ritual practices, offerings, and taboos that are believed by the community if not implemented to harm both the baby to be born and the mother herself. So, in pregnancy, ritual practices and various kinds of taboos and prohibitions often appear. 
TABle 2: Bugis community local wisdom activities related to pregnancy.

\begin{tabular}{|c|c|c|}
\hline No. & $\begin{array}{l}\text { Informant's } \\
\text { initials }\end{array}$ & Content analysis \\
\hline 1 & SN & $\begin{array}{l}\text { Makkatenni Sanro (held by the shaman) since the early months, our family has always had Sanro accompanying } \\
\text { us, whenever there is a pregnant person at home, they always entrust Sanro to attend them during childbirth, as } \\
\text { well as the seven-monthly ceremony }\end{array}$ \\
\hline 2 & RW & $\begin{array}{l}\text { I still chose a dukun to accompany me during childbirth; however, medical personnel assisted my delivery. I still } \\
\text { needed a dukun. My parents were escorted to the dukun's house in the second month. I also still do the seven- } \\
\text { monthly ceremony; I do this because my parents take care of everything. In the seventh month, there is a prayer } \\
\text { ceremony at home }\end{array}$ \\
\hline 3 & ST & My parents and in-laws asked when seven monthly, but I didn't do the seven-month event \\
\hline 4 & WD & $\begin{array}{c}\text { Makkatenni Sanro since the beginning of the family, there is always Sanro who accompanies. I still choose a } \\
\text { dukun to attend me during childbirth, which is my parents' will }\end{array}$ \\
\hline 5 & SR & $\begin{array}{l}\text { Makkatenni Sanro, Mappanre to Mangideng, and the seven-month pregnancy event, I did not do all three events } \\
\text { For Makkatenni Sanro, I still chooses shamans to assist in the delivery process; this is based on the parents' will. }\end{array}$ \\
\hline 6 & $\mathrm{HN}$ & $\begin{array}{l}\text { Still, they do not carry out Mappanre (feeding) to Mangideng (cravings) activities during pregnancy, and for the } \\
\text { seven-month pregnancy event, I have not carried out these activities }\end{array}$ \\
\hline 7 & WH & $\begin{array}{c}\text { Makkatenni Sanro and Mappanre to Mangideng, I'm still doing this, and so are my pregnant neighbors. However, } \\
\text { for the seven-month event, I have not done these activities }\end{array}$ \\
\hline 8 & KL & $\begin{array}{l}\text { Makkatenni Sanro, Mappanre to Mangideng, and the seven-month event, I still do it and choose a shaman to take } \\
\text { care of my pregnancy until delivery. Nearest neighbors and family support my actions }\end{array}$ \\
\hline 9 & SP & $\begin{array}{l}\text { For Makkatenni Sanro, I still chose a shaman when I was pregnant of my own volition, and most of the people in } \\
\text { the neighborhood where I also lived still chose a shaman when I was pregnant. I still do this activity at my family's } \\
\text { will for the seven-month event, and the community around me is still carrying it out }\end{array}$ \\
\hline 10 & $\mathrm{HL}$ & $\begin{array}{l}\text { I still chose a shaman when I was pregnant on the wishes of my parents-in-law. This activity is also still carried out } \\
\text { by the community in the area where I live, and for the seven-month pregnancy event, I still carry out these } \\
\text { activities as well as in the environment around me at the will of the family }\end{array}$ \\
\hline 11 & HD & $\begin{array}{l}\text { For Makkatenni Sanro, I still choose shamans during pregnancy. After pregnancy, I usually massage this because } \\
\text { based on the will of my parents and the community in my environment still use the services of shamans during } \\
\text { pregnancy until the delivery process. For the seven-month event, I did it based on my parents' will, and many } \\
\text { people still do it because it is a local community tradition }\end{array}$ \\
\hline 12 & HS & $\begin{array}{l}\text { Makkatenni Sanro during my pregnancy, I still did it and chose a dukun to accompany me during my pregnancy. } \\
\text { Mappanre to Mangideng. I don't do these activities, but I still do for the seven-month event }\end{array}$ \\
\hline
\end{tabular}

\section{Discussion}

5.1. Prenatal Education in the Class of Pregnant Women. Pregnancy is a time when a woman experiences many changes in her body, starting from changes in emotions, changes in body shape, changes in activity, and changes in diet. Because of this significant change, few pregnant women are compassionate. To reduce these sensitive feelings, some simple exercises can be done every day to get a feeling of happiness, comfort, and calm during pregnancy. Quoted from the parents.com page, some simple activities that mothers can do to always be happy during pregnancy are taking classes for pregnant women, eating balanced foods, and maintaining weight.

The daily activities of pregnant women in the class for pregnant women generally get actions in health counseling. Some pregnant women also state that there are gymnastics activities for pregnant women. The first material is about pregnancy, body changes, complaints that discuss what pregnancy is, changes in the mother's body during pregnancy, common complaints during pregnancy and how to overcome them (leg cramps, hemorrhoids, and low back pain), what pregnant women need to do, and nutritional arrangements including administration of blood-added tablets for the prevention of anemia. The second material includes childbirth which discusses the signs of labor, the danger signs of birth, and childbirth. The following material is postpartum care which discusses what postpartum mothers do to breastfeed breast milk exclusively. Taking care of postpartum health is very important. The third material discussed is baby care.

Classes for pregnant women are a means to learn together about health for pregnant women, in the form of face to face in groups that aim to increase knowledge and skills of mothers regarding pregnancy, pregnancy care, childbirth, postpartum care, and newborn care [32]. The results of this study are supported by research conducted by LS Ferawati [33], which states that there is a link between the activeness of pregnant women in participating in maternal classes and readiness to face the birth process. Pregnant women actively participate in mother's class activities and get helpful information about pregnancy, childbirth, and postpartum, and receive pregnancy exercise training. Pregnant women are better prepared to face the labor process by providing the correct information.

The results of this study can be concluded that classes for pregnant women can add insight and knowledge about pregnancy, childbirth, and postpartum and get pregnant exercise training through counseling conducted by health workers. Researchers found that the activities of pregnant women in Sidenreng Rappang district were running 
according to the guidelines of the Ministry of Health of the Republic of Indonesia, including conducting regular counseling and providing education to pregnant women. Classes of pregnant women get education through medical health services. Best education models for pregnant women are counseling, discussion with others to share how to control emotion, and also consumption of vitamin supplements for health.

\subsection{Bugis Community Local Wisdom Activities Related to the} Prenatal Period. The local wisdom of the Bugis community is very strict; considering the findings of the pregnant women studied even though there was a midwife, all pregnant women in Buginess to accompany them during pregnancy until delivery. Holding rituals has been believed to correlate with maternal and fetal safety during pregnancy, birth, and postpartum. The traditional ceremony devoted to pregnant women is an extraordinary psychological, physical, and social support passed down from generation to generation. It also contains spiritual values that are adapted to their respective religions. Traditional ceremonies for pregnant women will also give them self-confidence, strengthen mothers in the transitional period of changing their roles as mothers, change the mother's perspective on body changes during pregnancy, and increase a sense of security and feelings of respect.

The social support in the form of cultural rituals during pregnancy has several purposes and reasons, including (1) a ritual of salvation in which various special foods are beneficial for the mother's pregnancy; (2) the gathering of family and closest people during the event as a form of acceptance of the mother's pregnancy and also as a form of social support; (3) as a cultural effort to protect the pregnancy of the mother and child from evil spirits; (4) as a form of joint application so that the delivery will proceed normally; (5) as an effort so that the fetus grows in perfect health and goodness always covers the future baby [34]. In this tradition, there are several social supports that a mother gets during pregnancy, including (1) emotional support, (2) esteem support; (3) informational support; (4) instrumental support, and (5) companionship support.

Various groups of people in multiple places focus their attention on the cultural aspects of pregnancy and regard it as the stages of life that must be lived in the world. For both the fetus or baby and mother, the period of pregnancy and birth is a problematic crisis period since from pregnancy until the birth, a series of ceremonies are held for pregnant women to seek safety for the woman and her baby $[35,36]$.

The peak of local wisdom activities of the Bugis community is the 7 (seven) monthly event; because the event is massive, ritual tools are also many; Sanro always advises the class of pregnant women related to ethics, aesthetics, and metaphysics. Ethics are related to behavior and attitudes during pregnancy, corresponding to local wisdom. Its aesthetic value is associated with the pleasure and joy of pregnant women in carrying out rituals and metaphysics related to religious traditions and culture. The class of pregnant women is essential to carry out fun activities, according to their habit, as long as it does not violate the medical rules, local wisdom, and religion that it embraces.

\subsection{The Behavior of Pregnant Women as a Model of Prenatal} Education. The behavior of pregnant women affecting the fetus in the womb is an aspect that requires a prenatal education model. Prenatal education models are pregnant women's behavior, active learning and problem-based strategies, diverse methods, environmental-based media and learning resources, information technology, an orderly and continuous assessment system, medical-based materials, and community wisdom-based approaches. Some of the behaviors of pregnant women as the basis for formulating a prenatal education model are as follows:

(a) Pregnant women who have fun activities make the fetus calm, namely, the psychological influence of pregnant women on the fetus that soothes to form bonds with the fetus. Pregnant women are to put oil on the stomach and massage it slowly. There is nothing wrong with giving cream or oil to soothe the fetus during pregnancy after doing all the daily activities. An aromatherapy massage is a psychological influence of pregnant women on the fetus, which is suitable for pampering and taking time to think about the fetus. Pregnant women can talk to fetuses to stay calm.

(b) The healthy psyche of pregnant women makes the fetus happy, which is one of the psychological effects of pregnant women on a good fetus to relieve the legs while thinking about how it feels to be a fetus in the womb, namely, by swimming. Swimming not only is a safe sport but also provides an opportunity for pregnant women to judge the state of the fetus. Pregnant women are currently also floating in the water (amniotic fluid).

(c) A good mood for pregnant women makes the fetus smart; namely, the voice of the pregnant mother can help the fetus immediately form a bond with the pregnant mother after she is born. One theory is that the baby's hearing is well-developed in the womb to help it develop a bond with the expectant mother even though she is not yet born. After birth, your fetus may also pay more attention to your voice than to the agents of other people. Talking will be more enjoyable if you know that you can hear it. Pregnant women may feel a little embarrassed at first because they feel like they are talking to themselves, but they will get used to talking to their stomachs over time.

(d) Relaxing thoughts for pregnant women also make the fetus relax; namely, soaking in a tub filled with warm water is one of the psychological effects of pregnant women on the fetus to relax. This activity also provides an opportunity for pregnant women to 
spend time and pay attention to the fetus of pregnant women. Pregnant women may want to soak for a long time but make sure that the water is not too hot when you enter the tub.

(e) Pregnant women's views on birth affecting fetus feelings: pregnant women will learn the basics of light stretching and breathing techniques that can help pregnant women during childbirth. Prenatal yoga can help pregnant women calm the mind, relax the body, and help pregnant women feel connected with the fetus in the womb.

(f) Hypnobirthing makes the psychic fetus feel cared for, namely, giving birth using hypnotherapy techniques to help pregnant women focus on the fetus and the pregnant woman's body as the psychological influence of pregnant women on the fetus facing the birth process. Hypnobirthing technique can explain to pregnant women the psychological impact on the fetus to deal with pain during the birth process.

(g) Fetuses are happy when they are close to their fathers; when pregnant women are getting bigger, they can help their partners build close bonds with the fetus and to feel the movement of the fetus. From the 23rd week, a pregnant woman's fetus can already hear sounds that is heard from outside the uterus. So, a pregnant woman can talk to the fetus and invite her partner to read to her stomach. This helps the fetus of a pregnant woman adapt to the father's voice.

(h) Healthy lifestyle makes fetus healthy: it takes time for pregnant women to walk. Traveling gives pregnant women space to think about their fetus. Pregnant women can also talk to the belly of pregnant women while walking.

(i) Responding to fetal movements affects psychic and fetal activity, namely, pregnant women communicating with him before he was born. And pregnant women can do it wherever there are. By rubbing their belly, they can feel a kick. There is nothing more enjoyable than feeling your baby's fetus respond to your touch for the first time.

(j) Stressed pregnant women make unhealthy fetuses; namely, of course, some pregnant women are stressed due to various things, for example, because of economic problems, family, or the pregnancy itself; pregnant women who are not happy or feel stressed and sad about their pregnancy will undoubtedly make the fetus condition not healthy because it is affected by the psyche of his mother.

(k) Pregnant women reduce traits and habits to the fetus; namely, pregnant women who have the habit of being angry, smiling, patient, and so on will also affect the fetus they are carrying because the fetus will imitate what their mother did in the womb.
(1) Pregnant women with favorable religious conditions also have an impact on the fetus; that is, pregnant women who are calm because they have a strong faith or religion give their feelings of peace and belief in positive things about their pregnancy and the fetus in the future; therefore, this peace will also be felt by the fetus.

\section{Conclusion}

The daily activities of pregnant women carry out their duties as housewives. Marriage for women makes them understand their responsibility to care for and serve their husbands, as housewives and mothers of children. Amid the busyness and helplessness of pregnant women, they continue to participate in health education from the government with materials related to pregnancy, childbirth, postpartum, "family planning," and baby care. Some pregnant women also participate in gymnastics activities. Pregnant women are still obedient and obedient to local wisdom, especially the Bugis related to the prenatal period. All pregnant women studied used a Sanro (maternity dukun) to accompany them from pregnancy until delivery, even though there was a midwife (medical staff).

Regarding the 7 -month event, $75 \%$ of pregnant women still do it. The participation of pregnant women in events based on local wisdom is more dominant at the insistence of their parents, in-laws, and the closest family of their neighbors. Thus, medical personnel and birth attendants become educators for pregnant women in pregnancy, leading to the birth of a child. The prenatal education model is oriented to pregnant women, problem-based active learning strategies, varied methods, medical-based teaching materials, local wisdom, environmental-based learning media and resources and information technology, periodic and continuous evaluation systems, and medical personnel and birth attendants who become educators for pregnant women in the process of pregnancy towards the birth of a child. The prenatal education model is oriented to pregnant women, problem-based active learning strategies, varied methods, medical-based teaching materials, local wisdom, environmental-based learning media and resources and information technology, periodic and continuous evaluation systems, and medical personnel and birth attendants who become educators for pregnant women in the process of pregnancy towards the birth of a child. The prenatal education model is oriented to pregnant women, problem-based active learning strategies, varied methods, medical-based teaching materials, local wisdom, environmental-based learning media and resources and information technology, and periodic and continuous evaluation systems.

\section{Data Availability}

The underlying data supporting the results of your study can be found in Results and Discussion. 


\section{Additional Points}

Recommendations. Researchers in the fields of education, medical, and local culture should be more intense in researching to solve problems for pregnant women to reduce pregnancy problems and reduce mortality for pregnant women. This research aims to teach practitioners, medical personnel, and birth attendants to be more professional and humane in providing services to pregnant women for the safety of pregnant women and their children.

\section{Conflicts of Interest}

The authors declare that they have no conflicts of interest.

\section{Authors' Contributions}

Wardah Hanafie Das contributed to concept, design, and critical revision of the manuscript; Halik contributed to data analysis/interpretation, statistical analysis, and drafting the manuscript; Ahdar contributed to data acquisition, admin, and supervision; Bustanul Iman contributed to securing funding, technical or material support, and final approval.

\section{Acknowledgments}

The authors would like to thank the Ministry of Education, Culture, Research and Technology (KemendikbudRistek RI) of the Republic of Indonesia for its support and research partners related to the scientific development, interests and progress of the community. The authors would also like to thank the University Prime Minister Muhammadiyah Parepare for providing the facilities for the effectiveness of this study. This study was supported by the Ministry of Education, Culture, Research and Technology (KemendikbudRistek RI) of the Republic of Indonesia and the University of Muhammadiya in Parepare.

\section{References}

[1] O. Stephanie, M. Obrowski, and K. Starski, "Normal pregnancy: a clinical review," Academic Journal of Pediatrics \& Neonatology, vol. 1, no. 1, pp. 0015-0018, 2016.

[2] W. Aprilia, "Perkembangan pada masa pranatal dan kelahiran," Yaa Bunayya: Journal of Early Childhood Education, vol. 4, no. 1, pp. 39-55, 2020.

[3] W. Sallenbach, Mencetak Anak Laki-Laki Hebat, PT Gramedia, Jakarta, Indonesia, 1998.

[4] I. Nugraheni and K. Kuswati, "Perbedaan tingkat kecemasan ibu bersalin pada kelas ibu hamil di wilayah kerja puskesmas tulung," Jurnal Kebidanan dan Kesehatan Tradisional, vol. 2, no. 2, pp. 85-90, 2017.

[5] Indonesian Ministry of Health, Pedoman Pelayanan Gizi di Indonesia, Ministry of Health RI, Jakarta, Indonesia, 2017.

[6] Kusmiyati, Perawatan Persalinan (Perawatan Ibu Hamil [Maternity Care (Pregnant Mother Care)]Fitramaya Publisher, Yogyakarta, Indonesia, 2013.

[7] E. Elizawarda, "Hubungan kehamilan lewat waktu dengan kejadian bayi lahir asfiksiadi RSUP H. Adam malik medan," Jurnal Ilmiah PANNMED (Pharmacist, Analyst, Nurse,
Nutrition, Midwivery, Environment, Dentist), vol. 11, no. 2, pp. 108-112, 2016.

[8] K. Kambali, "Pertumbuhan dan perkembangan emosional serta intelektual di masa prenatal," Minutes: Journal of Islamic Education and Studies, vol. 4, no. 2, pp. 129-148, 2018.

[9] F. Utama and E. Prasetiawati, "Parental dalam pendidikan islam: studi pola asuh orang tua, dan materi pembelajaran perspektif pendidikan islam terhadap anak dalam kandungan masa prenatal," AL-MURABBI: Jurnal Studi Kependidikan dan Keislaman, vol. 7, no. 1, pp. 28-43, 2020.

[10] U. N. Islam, Mendidik Anak Dalam Kandungan Optimalisasi Potensi Anak Sejak Dini, Gema Insan, Jakarta, Indonesia, 2004.

[11] T. Andiyanto, "Konsep pendidikan pranatal, postnatal, dan pendidikan sepanjang hayat," Elementary: Jurnal Ilmiah Pendidikan Dasar, vol. 4, no. 2, pp. 195-203, 2018.

[12] M. Abdullah, "Telaah pemikiran ibn qayyim al-jauziyyah dalam kitab tuhfah al maudud bi ahkam al-maulud dan relevansinya dengan pendidikan islam," Al-Murabbi: Journal of Islamic Religious Education, vol. 2, no. 2, pp. 341-359, 2017.

[13] S. Khaira, E. Susilawati, L. Khaira, and I. Pratama, "Antecedents to student loyalty in Indonesian higher education institutions: the mediating role of technology innovation," Educational Sciences: Theory and Practice, vol. 21, no. 3, pp. 40-56, 2021.

[14] M. Ma'ruf, "Konsep pendidikan pranatal perspektif Islam," Al-Makrifat Journal, vol. 2, no. 2, pp. 124-137, 2017.

[15] Rasyim, A. Ibn, and H. Sa'diyah, "Pendidikan anak pranatal menurut ajaran islam [prenatal child education according to islamic teachings]," Journal of Axiom Ad-Diniyah, vol. 1, no. 1, pp. 53-64, 2015.

[16] Miftahillah, "Urgensi pendidikan pranatal bagi ibu hamil," Seling: Journal of the PGRA Study Program, vol. 2, no. 2, pp. 150-169, 2016.

[17] Manuaba and I. A. Chandranita, Obstetri. Ginekologi dan Keluarga Berencana, EGC, Jakarta, Indonesia, 2012.

[18] Purwoastuti and Walyani, Asuhan Kebidanan Nifas dan Menyusui, New Press Library, Yogyakarta, Indonesia, 2015.

[19] D. M. M. Kes, "Charismatic shaman-child and synergy towards midwives in the election of give birth, in south sulawesi, Indonesia: case study on maternal-child sorcerers ratings," Journal of Medical Science and Clinical Research, vol. 05, no. 04, pp. 20940-20946, 2017.

[20] E. Syarif, S. Sumarmi, and I. K. Astina, "Integrasi nilai budaya etnis bugis makassar dalam proses pembelajaran sebagai salah satu strategi menghadapi era masyarakat ekonomi ASEAN (MEA)," Jurnal Teori dan Praksis Pembelajaran IPS, vol. 1, no. 1, pp. 13-21, 2016.

[21] D. Handayani and S. Sunarso, "Eksistensi budaya pappaseng sebagai sarana pendidikan moral," Mudra Jurnal Seni Budaya, vol. 35, no. 2, pp. 232-241, 2020.

[22] M. Ali and M. Asrori, Metodologi dan Aplikasi Riset Pendidikan, PT Bumi Aksara, Jakarta, Indonesia, 2014.

[23] Emir, Metodologi Penelitian Pendidikan, King Grafindo Persada, Depok, Indonesia, 2013.

[24] Sugiyono, Metode Penelitian Kuantitatif, Kualitatif, dan R \& $D$, Alfabeta, Bandung, Indonesia, 2012.

[25] S. Arikunto, Prosedur Penelitian Suatu Pendekatan Praktis, Rineka Cipta, Jakarta, Indonesia, 2006.

[26] L. J. Moelong, Metodologi Penelitian Kualitatif, Rosdakarya Youth, Bandung, Indonesia, 2013.

[27] M. B. Miles and A. Michael Huberman, Qualitative Data Analysis, UI Press, Jakarta, Indonesia, 2005. 
[28] N. Fielding, R. M. Lee, and G. Blank, Eds., The SAGE Handbook of Online Research Methods, Sage, Thousand Oaks, CA, USA, 2008.

[29] S. Sarantakos, Social Research, MacMillan Education, Brisbane, Australia, 1993.

[30] Sugiyono, 2011, Metode Penelitian Kuantitatif, Kualitatif, Dan R \& D [Qualitative Quantitative Research Methods and R \& D], Bandung: Alfabeta, Departemen, Kesehatan, Indonesia.

[31] Sugiyono, 2007, Metode Penelitian Kuantitatif Kualitatif dan R\&D, Bandung: Alfabeta.

[32] Departemen Kesehatan RI, 2009, Pedoman Pelaksanaan Program Rumah Sakit saying Ibu dan bayi (RSSIB), Jakarta: Depkes RI.

[33] Ferawati, "Hubungan dukungan keluarga dan perilaku pengelolaan penyakit diabetes melitus tipe 2 di wilayah kerja puskesmas purnama kecamatan pontianak selatan kota pontianak," Jurnal Mahasiswa PSPD FK Universitas Tanjungpura, vol. 1, no. 1, 2014.

[34] A. P. P. Rahmawati, D. J. Lestari, and M. Saripudin, "Ritual budaya selama kehamilan di indonesia sebagai bentuk local wisdom dukungan sosial," Proceedings of the FKIP National Education Seminar, vol. 3, no. 1, pp. 502-514, 2020.

[35] Alkhaldi, C. Vadivu, and A. A. Alkhaldi, "ESL materials selection: key principles and suggestions," Educational Sciences: Theory and Practice, vol. 21, no. 3, pp. 12-26, 2021.

[36] S. V. Vadivu and S. Chupradit, "Psychosocial and occupational impact assessment due to internet addiction: A critical review," Systematic Reviews in Pharmacy, vol. 11, no. 7, pp. 152-155, 2020. 